\title{
Development Of Guided Discovery Based Electronic Module For Chemical Lessons In Redox Reaction Materials
}

\author{
https://doi.org/10.3991/ijim.v15i07.21559
}

Dewi Handayani $\left.{ }^{\varpi}\right)$, Elvinawati, Isnaeni University of Bengkulu, Bengkulu, Indonesia

d.handayani@unib.ac.id

Muzanip Alperi

Institution of Education Quality Assurance, Bengkulu, Indonesia

\begin{abstract}
This research is the development of guided disvovery based electronic module that aims to knowing the eligibility level of e-modules and student responses to guided discovery based electronic modules in redox reaction material. This electronic module uses the ADDIE development model. Research was conducted at one of the high schools in Bengkulu with the subject 9 students of X MIPA A Students for small scale trials and 30 students of X MIPA D Students for large scale trials. From the results of the research obtained (1) the percentage of feasibility of e-modules on the material aspect is $86,315 \%$ while from the media aspect is $91.425 \%$ so that based on the results of validation by the E-module validator is declared very valid, (2) based on the test results of the small-scale student response percentage of $75.97 \%$ with interesting category, while for large-scale trials of $84.48 \%$ with a very interesting category. From the results percentage, it can be concluded that e-module is suitable for use in learning. Electronic modul based on guided discovery is an effective tool to help students in learning redox reaction subject. E-modul can be accessed by smartphone or laptop. With this e-modul, students can access the study material from everywhere without any time limitation.
\end{abstract}

Keywords-Electronic Modules, Guided Discovery, Redox Reaction Materials

\section{$1 \quad$ Introduction}

Books are a learning support tool for students to dig up informations, concepts, and gain knowledge as well as chemistry textbooks. In learning activities, chemistry textbooks are one of the learning resources that are often used by teachers and high school students to support the learning process. Chemistry textbooks contain information about subject matters, examples and practice questions, as well as supporting pictures that are useful for students in understanding learning concepts. 
Chemistry textbooks should be an effective learning tool to help students achieve learning competencies and understand subject matter however from the results of observations made on class X one of the high schools in Bengkulu, it was found that students had difficulty understanding the explanation of the material in the chemistry textbooks that used. The lack of variations in sample questions also makes students difficult to understand the subject matter in chemistry textbooks, so that students find it difficult to understand the concepts and theories being studied. The results of the observations were supported by data obtained through questionnaires that were distributed to Bengukulu high schools. It is known that only about $44 \%$ of students are interested in reading chemistry textbooks and as many as $52 \%$ of students have difficulty understanding the explanations in chemistry textbooks.

The redox reaction is one of the materials that students learn in class $\mathrm{X}$ in the even semester, from the observation that data is obtained that only about $49 \%$ of students from class X MIPA in the 2018/2019 academic year at one of the high schools in Bengkulu passed the KKM on daily test and as many as $63 \%$ of students have difficulty studying redox reaction material. Research by Sulalaha, et al [1] also states that the results of the percentage of difficulties experienced by students in understanding redox material are quite large, namely the redox concept in terms of changes in oxidation number $(56 \%)$, oxidizing and reducing agents $(48 \%)$, releasing and receiving electrons $(45 \%)$, and binding and releasing oxygen $(39 \%)$.

In order to support student learning needs, various types of teaching materials have been developed, one of which is by utilizing technology. One form of technology use in education is the development of electronic modules. An electronic module is a form of presenting independent learning materials that are arranged systematically into the smallest learning unit to achieve certain learning objectives which are presented in an electronic format in which there are animation, audio, navigation that make users more interactive with the program [2]. As for electronic devices that can be used to access electronic modules, namely smartphone or laptop which have a number of supporting devices, making them more interactive and interesting. This is in line with previous research, namely Android-Based Interactive Mobile Learning has succeeded in creating new effective ways for students to learn [3]. Learning science by using an Android can improve the critical thinking skills of junior high school students [4].

In electronic module development, there is a number of applications that can be used, including 3D PageFlip Professional. The 3D PageFlip Professional software can add animation, images, audio, video, and audio-visual to support the media components of the e-module. The resulting electronic module can be saved in EXE, Zip, HTML, 3DP, or screen saver formats, so that it can be accessed using such as a PC / laptop and smartphone. Application 3D PageFlip Professional chosen for electronic module development because of its easy operation (user friendly), giving effect three dimensions, and has a more attractive appearance.

In order to develop an electronic module that can improve the quality of student learning, the guided discovery approach is adapted. The guide discovery approach will train students to find a concept actively, independently and with direction in order to strengthen students' understanding based on the results of the analysis they have done themselves. Guided discovery learning can be an efficient approach to teaching 
procedural skills, effectively to improve students' reflective thinking ability and student's self-learning both in high-rank school and middle-rank school $[5,6]$. Based on the background of the problems that have been described, the researchers conducted research with the title "Development Of Guided Discovery Based Electronic Module For Chemical Lessons In Redox Reaction Materials ".

\section{$2 \quad$ Literature Review}

\subsection{Electronic module}

E-module is the latest innovation from the print module, where this electronic module can be accessed with the help of a computer that is integrated with software that supports e-module access. Electronic media that can be accessed by students have different benefits and characteristics. If viewed from the benefits of electronic media itself, it can make the learning process more interesting, interactive, can be done anytime and anywhere and can improve the quality of learning. E-module development can be developed with various learning methods and the help of other supporting media. E-modules are a set of digital and non-printed teaching media that are systematically arranged and used for independent learning purposes, so that they can require students to learn to solve problems in their own way. E-modules are learning materials that are systematically designed based on a specific curriculum and are packaged in a specific time unit displayed using an electronic device such as a computer or android.

The electronic module is a form of presenting independent learning materials that are systematically arranged in the smallest learning unit to achieve a specific learning goal, which is presented in an electronic format [7]. The electronic module is a form of presenting independent learning materials that are arranged systematically into the smallest learning unit to achieve certain learning objectives which are presented in an electronic format in which there are animation, audio, navigation which makes users more interactive with the program.

\subsection{D Pageflip professional}

3D PageFlip Professional is a software that can be used to create teaching materials with $3 \mathrm{D}$ effects. This application is able to make the display of the electronic module more attractive with the addition of animation, images, video, audio-visual, various formats such as EXE, Zip, HTML, 3DP, Screen Saver and others. This 3D PageFlip Professional application also provides settings such as magazines, documents and so on [8]. 3D Pageflip software is a type of software used to convert teaching materials in PDF form to flipbook pages (back and forth), each resulting PDF page can be flipped like a real book and can also insert video in its production. flash, images and sound into the teaching materials that will be made so that the resulting 
teaching materials will be more interesting and can help students learn both independently and with teacher guidance.

To display electronic modules on an android system, it is necessary to first install the 3D Pageflip Reader application on the playstore or on the web www.3dpageflip.com. After installing 3D Pageflip Reader on the android system, the electronic module can be opened, which data has been entered into the smartphone first. Advantages in the 3D Pageflip Professional application, namely:

1. Flipbook media can be folded (back and forth) like a real book. When turning the page, it looks like it moves like flipping a book, causing a different and more interesting sensation.

2. In each page of the flipbook, an animation is inserted which supports the learning material in the form of a video or flash animation.

3. The e-book from the 3D Pageflip Professional application is an interactive learning medium in delivering material because it can display multimedia illustrations.

\subsection{Guided discovery}

Guided discovery is an approach which in its implementation is carried out by students based on teacher instructions. Instructions are given generally in the form of guiding statements, here the teacher as a facilitator, the teacher guides students where the teacher is needed. In this method, students are encouraged to think for themselves so that they can find general principles based on the material or data provided by the teacher. To what extent students are guided in learning depends on their abilities and what material is being studied [9]. Knowledge gained by discovery shows some goodness. First, it is long-lasting or long-remembered or easier to remember when compared to knowledge learned in other ways. Second, discovery learning outcomes have a better transfer effect than other learning outcomes. In other words, the concepts and principles that belong to one's cognitive are easier to apply to new situations. Third, thorough learning discovery improves learners' reasoning and ability to think freely [10].

There are guide discovery steps, namely student orientation to problems, organizing students in learning, conducting investigations, presenting the results of activities, and evaluating learning. This step makes students learn independently, actively, and creatively in obtaining their respective concepts and understanding [11].

The guided discovery approach guides students to be able to actively participate in the learning presented, students' problem-solving abilities will be honed, and the material studied will last longer because students are involved in the process of finding it [12].Guided discovery can train and improve some of the abilities of students. At the high school level, abilities that can be improved include problem solving skills and critical thinking skills. This indicates that guided discovery affects the thinking ability and activeness of students [13]. 


\section{Method}

\subsection{Research setting}

This research was conducted in the period of January-March 2020 at one of the high schools in Bengkulu City, Indonesia Class X MIPA for the 2019/2020 school year. The subjects of the small group trial were 9 students of class X MIPA A, while the subjects of the large group trial were students of class X MIPA. D totaled 36 students.

\subsection{Research design}

The research is development research or research \& development with the ADDIE model. This research consists of five stages of development including analysis, namely preliminary and final analysis, student's material analysis, task analysis, objectives of learning analysis. Furthermore, planning includes preparing references in the form of books and journals, compiling a conceptual framework, and compiling a module draft design. At the development stage, the e-module was made, expert validation, and revision then for implementation small group trials, stage II revisions, and large group trials were carried out.

\subsection{Data analysis technique}

Normality test: In the normality test using the Kolmogrov-Smirnov test through the IBM SPSS statistic 23 application program. The calculation results are stated to be normally distributed if the significance is $>0.05$ [14].

Validity e-modul analysis:

Table 1. Score of answers [15]

\begin{tabular}{|l|c|}
\hline \multicolumn{1}{|c|}{ Category } & Score \\
\hline Very good & 5 \\
\hline Well & 4 \\
\hline Pretty good & 3 \\
\hline Not good & 2 \\
\hline Not very good & 1 \\
\hline
\end{tabular}

The score obtained from the validity assessment is then calculated the average score using the following formula:

Information :

$$
\bar{X}=\frac{\sum x}{n}
$$

$\bar{X}=$ Average score

$\sum x=$ Total score of each statement

$n=$ Number of evaluators 
The calculation of the percentage of validity of each statement item of the e-modul uses the following formula:

$$
V=\frac{\text { Total score }}{\text { maximum score }} \times 100 \%
$$

Information :

$\mathrm{V}=$ Percentage of validity

Table 2. The percentage scale of the validity assessment [16]

\begin{tabular}{|l|l|}
\hline \multicolumn{1}{|c|}{ Category } & \multicolumn{1}{c|}{ Score666666666666666666666666 } \\
\hline $\mathrm{V}>80 \%$ & Very valid \\
\hline $41 \%<\mathrm{V} \leq 60 \%$ & Quite valid \\
\hline $21 \%<\mathrm{V} \leq 40 \%$ & Less valid \\
\hline $\mathrm{V} \leq 20 \%$ & Invalid \\
\hline
\end{tabular}

If the percentage of validity is less than the valid criteria, the guided discoverybased chemistry e-module must be revised again before proceeding to the next stage.

Product trial analysis

Table 3. Score of the answer choices [15]

\begin{tabular}{|l|c|}
\hline \multicolumn{1}{|c|}{ Category } & Score \\
\hline Strongly agree & 5 \\
\hline Agree & 4 \\
\hline Disagree less & 3 \\
\hline Disagree & 2 \\
\hline Strongly Disagree & 1 \\
\hline
\end{tabular}

The assessment score obtained from the answer choices available on the student response sheet is then calculated the average score using the following formula:

$$
\bar{X}=\frac{\sum x}{n}
$$

Information :

$\bar{X}=$ Average score

$\sum x=$ Total score of each statement

$\mathrm{N}=$ Number of evaluators

$$
R=\frac{\text { Total Score }}{\text { Maximum Score }} \times 100 \%
$$

Information :

$\mathrm{R}=$ percentage of student's responses 
Table 4. The percentage scale of student responses [16]

\begin{tabular}{|l|l|}
\hline \multicolumn{1}{|c|}{ Category } & \\
\hline $\mathrm{R}>80 \%$ & Very interesting \\
\hline $61 \%<\mathrm{R} \leq 80 \%$ & Interesting \\
\hline $41 \%<\mathrm{R} \leq 60 \%$ & Quite interesting \\
\hline $21 \%<\mathrm{R} \leq 40 \%$ & Less attractive \\
\hline $\mathrm{R} \leq 20 \%$ & Not attractive \\
\hline
\end{tabular}

If the percentage of student responses is less than the attractive criteria $(\leq 40 \%)$, the guided discovery-based chemistry e-module must be revised.

Analysis of students' level of understanding of the use of electronic modules: Analysis of the level of understanding of students seen from the cognitive aspects of students based on tests of student's understanding. To determine the effect of learning on Concept Mastery, an N-Gain Score analysis was carried out [17].

$$
\mathrm{N}-\text { Gain }=\frac{\text { postest score-pretest score }}{\text { maximum score- } \text { pretest score }}
$$

Description: N-Gain: Normalized gain pretest: The initial value of learning

Postest: The final grade of learning

Table 5. Criteria for Gain Index [18]

\begin{tabular}{|l|l|}
\hline \multicolumn{1}{|c|}{ N-Gain } & \multicolumn{1}{c|}{ Category } \\
\hline N-gain score $\geq 0.7$ & High \\
\hline $0.3 \leq$ N-gain score $<0.7$ & Moderate \\
\hline N-gain score $<0.3$ & Low \\
\hline
\end{tabular}

\section{$4 \quad$ Result and Discussion}

The guided discovery based electronic module was developed as a learning resource for students to help understand material through analysis and discovery activities. Guided discovery emphasizes the discovery of concepts or learning material by students themselves [19].

Based on research, normality test determination of the test subjects on a small and large scale.

Table 6. Data of Normality Test in Taking Research Subjects

\begin{tabular}{|l|c|c|l|}
\hline \multicolumn{1}{|c|}{ Class } & Sig Value Count & $\begin{array}{c}\text { Value of } \\
\text { Significance }\end{array}$ & \multicolumn{1}{c|}{ Decision } \\
\hline X MIPA A & 0.067 & 0.05 & Normal distribution \\
\hline X MIPA B & 0.004 & 0.05 & Not normally distributed \\
\hline X MIPA C & 0.012 & 0.05 & Not normally distributed \\
\hline X MIPA D & 0.092 & 0.05 & Normal distribution \\
\hline
\end{tabular}


From table 6. it is known that the significance value of class X MIPA A and X MIPA D > 0.05 which means normally distributed while X MIPA B and X MIPA C $<0.05$, that is, not normally distributed. Thus, class X MIPA A is for small scale trials and X MIPA D is for large scale trials.

E-module has passed the validity test by the validator by assessing the material and media aspects. In material aspects, there are various aspects in the e-module that must be revised in order to fix the parts in the e-module that are not yet suitable. Explains that revisions were made to improve the e-module part which was considered inaccurate by the validator before it was tested. After the revision was complete, the validator assessed that the media and material aspects of the guided discovery-based emodule were very valid with a percentage of $91,425 \%$ and $86,315 \%$. The validation results state that the e-module can be tested on students. E-module said to be feasible to be tested if it meets the level of validity [20].

Table 7. Feasibility Assessment of Guided Discovery-Based Chemical E-Module

\begin{tabular}{|c|l|c|c|l|}
\hline No. & Validation Aspects & $\begin{array}{c}\text { Score } \\
\text { Average }\end{array}$ & Percentage of Validity (\%) & Criteria \\
\hline 1 & Media & 96 & 91,425 & Very Valid \\
\hline 2 & Material & 82 & 86,315 & Very Valid \\
\hline
\end{tabular}

From table 7, it is known that the results of the e-module validation based on guided discovery by two validators on the media aspect obtained an average score of 96 if the percentage of validity was calculated, namely $91,425 \%$ with very valid criteria. In the validation of the material obtained a score of 82 with a validity percentage of $86,315 \%$ on very valid criteria. The data validation carried out by experts is explained as follows.

Media validation results

Table 8. Tabulation of Media Expert

\begin{tabular}{|c|c|c|c|c|c|c|}
\hline & \multicolumn{3}{|c|}{ Exfert Lecturer I } & \multicolumn{3}{|c|}{ Exfert Lecturer II } \\
\hline $\begin{array}{c}\text { Assessment } \\
\text { Aspects }\end{array}$ & $\begin{array}{l}\text { Total } \\
\text { score }\end{array}$ & $\begin{array}{c}\text { Percentage of } \\
\text { Validity (\%) }\end{array}$ & Criteria & Total score & $\begin{array}{c}\text { Percentage of } \\
\text { Validity (\%) }\end{array}$ & Criteria \\
\hline E-module layout & 30 & 100 & Very Valid & 25 & 83,3 & Very Valid \\
\hline \begin{tabular}{|l} 
E-module \\
graphics
\end{tabular} & 52 & 94,54 & Very Valid & 45 & 81,82 & Very Valid \\
\hline $\begin{array}{l}\text { E-module lan- } \\
\text { guage }\end{array}$ & 20 & 100 & Very Valid & 20 & 100 & Very Valid \\
\hline Total score & 102 & & & 90 & & \\
\hline Average $(\overline{\boldsymbol{X}})$ & 34 & $97,14 \%$ & Very Valid & 30 & $85,71 \%$ & Very Valid \\
\hline
\end{tabular}

In table 8, the total score exfert lecturer I and exfert lecturer II are 102 and 90 with a percentage of validity of 97,14 and $85,71 \%$ with very valid criteria, indicating that the e-module is very suitable for use by students.

Results of material validation: Based on research results, material validation was carried out by experts including lecturers in the chemistry education study program and chemis- 
try teacher at one of the high schools in Bengkulu City, Indonesia. The e-module assessment by material experts is presented in table 9 :

Table 9. Tabulation of Material Expert

\begin{tabular}{|l|c|c|l|c|c|c|}
\hline \multicolumn{1}{|c|}{$\begin{array}{c}\text { Assessment } \\
\text { Aspects }\end{array}$} & Total score & $\begin{array}{c}\text { Percentage } \\
\text { Validity (\%) }\end{array}$ & Criteria & $\begin{array}{c}\text { Total } \\
\text { score }\end{array}$ & $\begin{array}{c}\text { Percentage } \\
\text { Validity (\%) }\end{array}$ & Criteria \\
\hline Preliminary & 13 & 86,67 & Very Valid & 12 & 80 & Very Valid \\
\hline $\begin{array}{l}\text { Completeness of } \\
\text { contents }\end{array}$ & 28 & 93,33 & Very Valid & 23 & 76,67 & Very Valid \\
\hline Learning & 28 & 93,33 & Very Valid & 26 & 86,67 & Very Valid \\
\hline Guided Discovery & 18 & 90 & Very Valid & 16 & 80 & Very Valid \\
\hline Total score & 87 & & & 77 & & \\
\hline Average score $(\overline{\boldsymbol{X}})$ & 21,75 & $91,58 \%$ & Very Valid & 19,25 & $81,05 \%$ & Very Valid \\
\hline
\end{tabular}

In table 9, the total score exfert lecturer $\mathrm{I}$ is 87 with a validity percentage of $91,58 \%$, and total score expert lecturer II is 77 with a validity percentage of $81,05 \%$. The results of the assessment by two experts stated that the e-module was very valid.

In preparing the material into guided discovery-based e-modules, it is adjusted to the core competencies and indicators in the 2013 curriculum. The sub-material consists of:

1. Development of the Concept of Redox Reactions

2. Rules for Determination of Biloks

3. Reduction and Oxidation

4. Oxidizing and reducing agents

5. Disproportionation and Consproporsionation

The components included in the e-module are the preparation of contents that are adjusted to core competencies, basic competencies, and indicators, presentation format, and material systematics in the developed e-module. The content of the e-module consists of a discussion rubric, a description of the material, exercise I, exercise II, summary, evaluation, answer keys, glossary, and bibliography, as well as a video tutorial designed to help students understand how to solve problems independently.

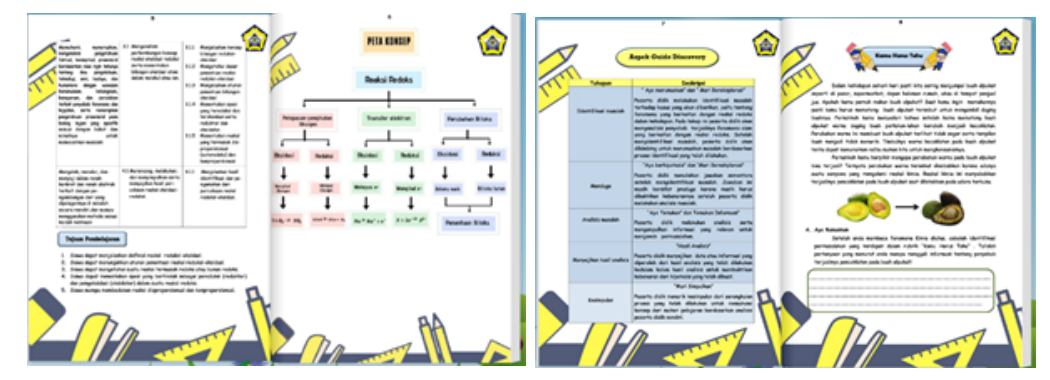

Fig. 1. The initial view of the e book 
The electronic module guided discovery-based was developed as a learning resource for students to help understanding material through analysis and discovery activities. The e-module is presented based on the component of the guided discovery approach which consists of let's formulate, let's hypothesize, let's analyze, let's collect data, and let's conclude. The guided discovery approach is used because it can train scientific thinking skills and guide students in finding concepts independently. According to Shinta [19], guided discovery emphasizes the discovery of concepts or learning material by students themselves.

In the guided discovery-based chemistry e-module trial phase, it is first disseminated, this is done so that students can read the e-module before learning activities in class are carried out and it is hoped that students will gain initial knowledge about the material. Then students are formed into groups and then given directions to read the rubric containing the material on the activity sheet. Students are given the opportunity to read and study various information contained in the rubric. When learning process used e-module students are able to receive directions well, students read the material in the rubric carefully with their group members. After students have finished reading the rubric, students are led to formulate problems based on the information students get. At first the students had experienced problems in writing the problem formulation, but students actively asked questions to overcome these obstacles. After being guided and given instructions, students can begin to formulate their own problems well.

In the let's hypothesize stage, students write down their answers temporarily to prove their truth through the analysis process. Some students were confused about writing hypotheses because this activity was very new to students. Students need to be taught in advance how to make hypotheses. In the activity let's analyze students observe the video displayed on e-module and try to find answers to prove the truth of hypotheses that students have conveyed. Students analyze the contents of the video to collect data and write down their observations on the worksheets provided. After going through all the stages of the activity, at the end of the discussion the students were guided to write conclusions based on the results of the analysis that had been done.

Guided discovery-based e-module implementation on research subjects: From the small-scale trial, the average score of the student response questionnaire was 60,78 , where the calculation of the percentage of student responses was obtained $75,97 \%$ with very interesting category. From a large-scale trial of the guided discovery-based chemical e-module, the percentage of the response was $84.48 \%$, with very interesting category.

In small-scale trials carried out on 9 students. When the small-scale trial was carried out, the e-module was provided offline in 3DP format and online using a link. Students can access the e-module using their mobile phone or laptop. From the trials conducted by students assessing the e-module is interesting because it can help in understanding the material, besides that the appearance and content of the e-module makes students motivated to study the material contained in the e-module, that learning resources interesting things will generate knowledge and motivate students in learning [19]. 
In a large-scale trial, guided discovery-based e-modules get a positive response from students assessing that e-modules help to study the material optimally. The arrangement of material and structured learning activities makes it easier for students to know the sequence of learning the material. Material arranged according to needs can lead students to construct their own knowledge [21]. In addition, multimedia (text, video and images) displayed on the e-module helps students to understand how to solve problems so that it fosters students' interest in studying redox reaction material. The use of digital books makes learning interesting, practical and can be carried anywhere because they can be read through smartphone [22].

From the research that has been done, it is known that the guided discovery based chemical electronic module is quite effective in helping students study redox reaction material. The results obtained are in accordance with Khasanah's research [23] that guided discovery-based modules are effective in helping students understand the material. The development of guided discovery-based e-module teaching materials is also able to stimulate students critical thinking skills, enhancing process skills and attitudes developing guided inquiry-based science teaching and learning [24, 25].

Learning activities that provide the widest possible opportunity for students to gather information and analyze can provide new learning experiences for students. Emodul can be accessed by smartphone or laptop has become more flexible. With this e-modul, students can access the study material from everywhere without any time limitation and students who do not have chemistry textbooks can learn through emodules.

\section{Conclusion}

Based on the validity test, it shows that the guided discovery-based e-module is very feasible to be used as a learning resource by students with a percentage of validity on the media aspect of $91.425 \%$ and the material aspect of $86,315 \%$ with a very valid category. From the trial stage students gave positive responses, that the emodule was very interesting and helped students understand the material with the percentage of the response, namely $84.48 \%$.

\section{References}

[1] Sulalaha, Wardha Anis, Ida Bagus Suryadharma and Dedek Sukarianingsih.( 2017). Analysis of the Difficulties of Remedial Participants in Understanding the Concept of Redox Reaction.Journal of Chemistry Learning. 2 (1): 14-20. ISSN: 2579-5945.

[2] Puspitasari, Anggraini Diah. (2019). Application of Learning Media for Physics Using Print Modules and Electronic Modules for High School Students. Journal of Physics Education.7 (1). e-ISSN 2550-0325.

[3] Ruhimat, T and Rosdiana, TR. (2020). Developing Android-Based Interactive Mobile Learning Software to Improve Students' Analysis and Synthesis Abilities on Basic Electronics. iJIM - Vol. 14, No. 20, 2020. https://doi.org/10.3991/ijim.v14i20.14879 
[4] Hasyim, F and Prastowo, T and Jatmiko, B. (2020). The Use of Android-Based PhET Simulation as an Effort to Improve Students' Critical Thinking Skills during the Covid-19 Pandemic. iJIM - Vol. 14, No. 19, 2020. https://doi.org/10.3991/ijim.v14i19.15701.

[5] Aagesen, Andreas H. MBBS; Jensen, Rune D. MSc, PhD; Cheung, Jeffrey J.H. MSc, PhD; Christensen, John B. MD; Konge, Lars MD, PhD; Brydges, Ryan MSc, PhD; Thinggaard, Ebbe MD, PhD; Kulasegaram, Kulamakan M. PhD. (2020). The Benefits of Tying Yourself in Knots, Academic Medicine: August 4, 2020 - Volume Publish Ahead of Print - Issue - https://doi.org/10.5055/ajdm.2015.0197.

[6] S H Noer et al. (2020). Development of guided discovery learning to improve students reflective thinking ability and self learning J. Phys.: Conf. Ser. 1581 012041. https://doi.org/ $10.1088 / 1742-6596 / 1581 / 1 / 012041$

[7] Adiputra,I.N. (2014). Pengembangan E-Modul pada Materi "Melakukan Instalasi Sistem Operasi Jaringan Berbasis GUI dan Text" untuk Siswa Kelas X Teknik Komputer dan Jaringan SMK Negeri 3 Singaraja. Jurnal Karmapati. 3 (1) . ISSN 2252-9063. https://doi. org/10.23887/karmapati.v6i1.9269

[8] Fitriyani. (2017). Pembelajaran Menggunakan Media 3D Pageflip Professional dan Media Camtasia Studio 8 pada Materi Larutan Elektrolit dan Non Elektrolit di Kelas X SMA Islam Al-Arief Muaro Jambi. Jurnal Pendidikan kimia.2 (4). https://doi.org/10.24014/kon figurasi.v3i2.7599

[9] Asri, Eka Yulia \& Sri Hastuti Noer.(2015). Guided Discovery Learning dalam Pembelajaran Matematika. ISBN. 978-602-73403-0-5

[10] Dahar, R. M. (2006). Teori-Teori Belajar dan Pembelajaran. Jakarta: Erlangga

[11] Saraswati, Anggi Meylia dan Christina Evi. (2018). Pengembangan Lembar Kegiatan Siswa (LKS) Berdasarkan Model Pembelajaran Guided Discovery. Jurnal Aksiom. 9 (1): 97. e-ISSN 2579-7646 . https://doi.org/10.26877/aks.v9i1.2516

[12] Setyaningtyas,Rizki Fitria. (2018). Pengembangan Modul IPA Berbasis Guided Discovery untuk Meningkatkan Literasi Sains. Jurnal Unej. 3. ISSN : $2527-5917$

[13] Pramunando, W \& Yerimadesi. (2019). Pengembangan Modul Ikatan Kimia Berbasis Guided Discovery Learning untuk Kelas X SMA. EduKimia Journal. 1(2). e-ISSN: 25026399. https://doi.org/10.24036/ekj.v1.i1.a1

[14] Kadir. (2016). Statistika Terapan: Konsep, Contoh, dan Analisis Data dengan Program SPSS/Lisrel dalam Penelitian Edisi Kedua. Jakarta: Rajawali Pers. ISBN 978-979-769900-0

[15] Sugiono. (2012). Metode Penelitian Kuantitatif, Kualitatif, dan R\&D. Bandung: Alfabeta. ISBN: 979-8433-64-0

[16] Suyanto, Eko \& Sartinem. (2009). Development of Sample Student Physics Worksheets with Background Completion of Initial Teaching Assignments and Process Skills for SMA Negeri 3 Bandar Lampung. Proceedings of the National Education Seminar 2009. Lampung: Unila.

[17] Amrullah, Ahmad Khoirussyifa, Muslimin Ibrahim, dan Wahono Widodo. (2017). Implementasi Pembelajaran Berbasis Masalah Untuk Melatihkan Kemampuan Berpikir Kreatif dan Penguasaan Konsep Siswa Kelas V Sekolah Dasar. Jurnal Review Pendidikan Dasar. 3(1) . e-ISSN: 2460-8475. https://doi.org/10.26740/jrpd.v3n1.p378-387

[18] Rahmawati, Sarah, Asri Widowato and Widodo Setyo Wibowo. (2017). Development of Virtual Science Laboratory with Inquiry Material Osmosis Approach to Improve Students' Analytical Ability. Journal of Natural Science Education. 6 (6)

[19] Shinta, Mardha and Lufri Abdul Razak. (2013). Character Education Oriented Biology Learning with Guided Discovery Approach on Animal Network Material for SMA / MA. Journal of Collaborative Education in Biology. 1 (1). ISSN: 2302-7592 
[20] Cheva, VK \& Zainul. R. (2019). Development of Guided Inquiry E-Module on Element Periodic Characteristics for Class X SMA / MA. Edukimia Journal, 1 (1), 28-36.

[21] Wulandari, Septiana, Endang Suarsini, and Ibrohim. (2016). The Utilization of Environmental Biotechnology Handout Learning Resources to Improve Undergraduate Students' Concept Understanding. Journal of Education: Research Theory. 1 (5). EISSN: 2502-471x.

[22] Handayani, D and Sundaryono, A. (2020). Chemical Practicum Development Organic 1 Using The Application Adobe Flash. PENDIPA Journal of Science Education, 2020: 4(2), 58-65. https://doi.org/10.33369/pendipa.4.2.58-65

[23] Khasanah,KD julfa and Triana Asih. (2017). Development of Guided Discovery Based Module on Protista Material for Biology Learning for Class X High School Students. repository.ummetro. ISBN: 978-602-70313-2-6.

[24] Sugiyarta, A. W., \& Suparman. (2019). Deskripsi E-Modul Berbasis Guided Discovery untuk Menstimulus Kemampuan Berpikir Kritis Siswa Slow Learner. Proceedings of The 1st STEEEM, 1(1), 76-83.

[25] 大谷強, Setiyadi, M. W., Saputra, A., Wahyuni, S., Program, M., Pendidikan, S., ... Supriadi, B. (2017). Pengembangan Modul Ipa Smp Berbasis Guided Inquiry Untuk Meningkatkan Keterampilan Proses Dan Sikap Developing a Guided Inquiry-Based Science Teaching and Learning. Unnes Science Education Journal, 3(1), 1496-1502. Retrieved from http://journal.unnes.ac.id/index.php/jpii. https://doi.org/10.24127/jpf.v3i1.21

\section{$7 \quad$ Authors}

Dewi Handayani is a lecturer in the Education Chemistry Study Program at the Department of Science Mayor Education at Universitas Bengkulu, Indonesia and now, she is postgraduate student, at the Department of Education, Faculty of Teacher Training and Education Universitas Bengkulu. (email: d.handayani@unib.ac.id).

Elvinawati is a lecturer in the Education Chemistry Study Program at the Department of Science Mayor Education at Universitas Bengkulu, Indonesia.

Isnaeni is an undergraduate student in the Education Chemistry Study Program at the Department of Science Mayor Education at Universitas Bengkulu, Indonesia.

Muzanip Alperi is an educational technology developer at_Institution of Education Quality Assurance, Bengkulu, Indonesia. and now, he is postgraduate student, at the Department of Education, Faculty of Teacher Training and Education Universitas Bengkulu.

Article submitted 2021-01-25. Resubmitted 2021-02-28. Final acceptance 2021-02-28. Final version published as submitted by the authors. 